\title{
3 The Wadden Sea region as a cultural landscape
}

\author{
History, heritage, management
}

Hans Renes

\begin{abstract}
The Wadden Sea region is a typical example of what is often called a 'maritime cultural landscape', a landscape that is shaped by the forces of nature and culture and also a landscape in which the livelihood of the population is built on the use of resources from the land as well as from the sea. The author looks at the complex relation between nature and society in the Wadden Sea region in the past as well as in the present. For the sustainable management of this region, an integrated approach combining developments in nature and society is necessary. The artificial border between nature and culture introduced by some ecologists and authorities (the most notorious example being the inscription of the Wadden Sea as a World Heritage Site) is a source of conflict and complicates an integral management of the Wadden Sea region. The author is convinced that the Wadden Sea should be seen as a cultural landscape.
\end{abstract}

Keywords: Wadden Sea region, maritime cultural landscape, nature and culture, integrated approach

For most people, the first association with the Wadden Sea is 'nature'. But it is nature that has for many centuries been used by people. Around the turn of the century, a perception map of the Wadden Sea region was made, showing a collection of people's associations with specific places in the Wadden Sea region (Van Marrewijk 2001: 169). Many of these memories are related to silence, space, vegetation or the weather, but we also find

Egberts, Linde \& Schroor, Meindert (eds.), Waddenland Outstanding: The History, Landscape and Cultural Heritage of the Wadden Sea Region. Amsterdam: Amsterdam University Press, 2018 DOI: $10.5117 / 9789462986602 / \mathrm{CHO} 3$ 
references to human activities and to the history of people and landscapes. The stories of the Wadden are about nature as well as landscape.

The main aim of this paper is to stress the importance of seeing the Wadden Sea region as a cultural landscape. Therefore, I start with some introductory remarks on the concepts of - and interrelations between nature and landscape. In the second part, I look at the history of the Wadden Sea region, focusing on the land-water interface. I finish with a few remarks on the Wadden Sea as a World Heritage Site.

\section{Nature and landscape}

Both landscape and nature are problematic concepts (Table 1). Landscape was originally almost synonymous with 'region', including the management and the managing organizations. This territorial meaning of landscape is still retained in the names of such organizations, for example the Ostfriesische Landschaft, as well as in definitions of landscapes used by landscape ecologists. During the Renaissance, another meaning of the word landscape developed when painters started to name their depictions of rural scenes 'landscapes'. From this, the visual meaning of the word landscape developed. Definitions of landscape differ by region. In Germany, for example, the original regional meaning is still very much alive, whereas in the UK the word landscape, which had disappeared during the Middle Ages, was reintroduced by painters from the Low Countries and therefore has a strongly visual meaning (Olwig, 2002).

Table 3.1 The concepts of landscape and nature

\begin{tabular}{|c|c|c|}
\hline & Landscape & Nature \\
\hline \multirow[t]{2}{*}{ Etymology } & 1 Region & 1 Character (human) \\
\hline & 2 Scenery & $\begin{array}{l}2 \text { That which develops without } \\
\text { human intervention }\end{array}$ \\
\hline $\begin{array}{l}\text { Meaning in landscape } \\
\text { ecology }\end{array}$ & Regional system & Regional system \\
\hline $\begin{array}{l}\text { Meaning among general } \\
\text { public }\end{array}$ & Scenery & $\begin{array}{l}\text { Scenery ('nature' is often } \\
\text { presented as 'landscape') }\end{array}$ \\
\hline $\begin{array}{l}\text { Meaning in politics and } \\
\text { governance }\end{array}$ & $\begin{array}{l}\text { Scenery, 'visual environ- } \\
\text { mental quality' }\end{array}$ & Area with designation 'nature' \\
\hline
\end{tabular}

Nature is usually described as that which exists without human interference. This concept of nature ranges from individual plants or animals to complex 
ecosystems. However, nature is often presented as landscape (take the many movies, books and leaflets in which nature is presented in beautiful pictures of what I would call landscapes). Hence, for many people the two are almost synonymous. In government policies, in which nature is always connected to concrete territories, regions with limited human influence are often called 'nature' as opposed to 'landscapes' that have a strong man-made character.

Both nature and landscape are broad, holistic concepts. Only in politics are nature and landscape completely disconnected. Nature is regionalised, as it is often used as a label for protected reserves. Landscape is usually seen as a quality connected to land that has other, often agrarian, primary functions. In some cases, landscapes are also regionalised, usually in processes in which man-made landscapes receive some kind of protection.

One problem with landscapes is often the formulation of aims. For a long time, landscape protection was backward-looking and only reactive, making it difficult to cooperate with more future-oriented landscape architects. During the early years of the present century, the heritage sector, which included historic landscapes, moved from a defensive attitude towards a more open, offensive approach (Janssen et al. 2017). The aim is no longer to protect those landscape objects that have survived twentieth-century modernisations (making the period around 1900 a point of reference) but to use historic landscapes as an asset in the making of future landscapes. But even then it is difficult to formulate landscape goals; only designers take steps in this direction. For nature, such a normative approach is much easier, for there is an assumption that a larger biodiversity is always better and that every landscape will improve by erasing or minimising human influence. Attempts to create more or less natural ecosystems are often labelled 'new nature' or 'new wilderness', sometimes with the claim of reconstructing 'complete' or 'pristine' nature.

This concept of a new wilderness has two major problems. The first is the unjustified claim that wilderness can exist that is pristine and free of human modification. This is certainly not true for the Wadden Sea, which is heavily used for fishing, recreational activities, etc. Moreover, the borders of the Wadden Sea are defined by man-made structures, such as dikes. Even the Wadden Sea itself is partly man-made. During the early Middle Ages, behind the coastal dunes a huge fenland existed, which was partly inhabited and reclaimed. Remains of this landscape are still visible on the well-known map by Christian 'sGrooten, made in the middle of the sixteenth century but probably containing some information from the fifteenth century. However, by that time huge areas had already disappeared when the sea made good use of the land subsidence in the reclaimed fenlands. Using a 
term coined by Bruno Latour, Olwig (2006) concludes that the Wadden Sea as pure nature is a constructed fact.

The second problem with the wilderness concept is the exclusion of people. The definitions for national parks, as they are still proclaimed by the International Union for the Conservation of Nature (IUCN), have elsewhere - in the past in the United States (for example in Yellowstone and Yosemite) and even still today in parts of Africa - led to human rights violations where groups of people that had managed the area for thousands of years and that were responsible for many of the values were evicted in the name of nature. They were reframed as poachers, which can best be defined as hunters belonging to the wrong social class. Wilderness is an idea rather than a biophysical reality.

It is interesting to look at the physical limits of the Wadden Sea as World Heritage Site (see figure 1.1). The Wadden Sea is surrounded by relatively densely populated areas. The official map of the Wadden Sea World Heritage Site shows how the designers of the nomination must have worked for days and nights drawing lines that excluded almost every individual inhabitant from the World Heritage area. The exclusion of people is a great recipe for problems. This became clear when Schleswig-Holstein designated a national park in the Wadden Sea region and, again, in the preparations for the nomination of the Wadden Sea as a natural UNESCO site (Krauss 2005; see also Van der Aa et al. 2004).

\section{The Wadden Sea region as a maritime cultural landscape}

It makes much more sense to see the Wadden Sea region as a cultural landscape that is shaped and reshaped by nature as well as by human society (Lotze et al. 2005). It is best seen as a maritime cultural landscape, as described by the archaeologist Christer Westerdahl (1992). Terminology such as (maritime) cultural landscape provides us with a framework within which the relations between nature and culture and between land and water can be understood.

To a large degree, the border between sea and land is the result of human activities. From the Iron Age to the High Middle Ages, land and sea were not strictly divided and borders between land and sea were gradual and dynamic. Such an 'amphibious environment' (Knottnerus 2004: 153) can nowadays still be felt in the Halligen. Seen from the water, the Halligen show themselves as a number of dwelling mounds that rise above the flat land or, in times of extremely high water levels, from the sea. 
Until the High Middle Ages, the coastal marshes as well as much of the islands were inundated with high tides - in some cases twice a day, in other cases only with extreme tides or storms. Typical for this land was a population that combined agriculture with trade and related activities. Some dwelling mounds seem to have been mainly occupied by traders and hand-workers, but most dwelling mounds must have had non-agrarian activities. Almost every dwelling mound had direct access to sea and to shipping. Agriculture consisted mainly of animal husbandry, although some arable production was possible. The focus on animal husbandry intensified the dependence on and exchange with other regions. The most quoted author on the Wadden Sea, the Roman writer Pliny the Younger, describes the region as marginal and as inhabited by poor and desperate people. But in reality, during the First Millennium this was a region with an extremely high population density that was certainly not poor given the standards of the period (Knol 2005).

Already during the times of Pliny the First, dikes were built, probably to extend the growing season for crops. But the situation changed dramatically during the High Middle Ages, when dikes were built all along the coast. The dwelling mounds lost their direct contact with the sea and with the maritime shipping routes, and gradually sea trade became concentrated in a small number of places on the coast. The process can be seen in the small town of Bolsward (figure 3.1), which was built around two old dwelling mounds, the original Bodilwerth, a settlement of craftsmen and traders, and the original Hockwerd, an agricultural settlement as well as an old religious centre with the mother church of the whole region of Westergo (Kullberg 1992). After the building of the dike, the Bodilwerth remained connected to the sea, but in the following centuries this connection disappeared as a result of land reclamations. After that, the town of Bolsward built a new position as a marketplace for the dairy farmers in the region. The canal through the town, the Grote Dijlakker, shows houses from the sixteenth to eighteenth centuries that in their building style betray connections to Amsterdam.

The example shows that while dike-building made a significant difference, it did not completely disconnect land and water. Moreover, most of the medieval dikes were low and vulnerable, and some were so low that it was still possible to improve the land by floods that brought fertile silt. This changed in many parts of the Wadden Sea region only during the sixteenth and seventeenth centuries, when an orientation towards the Amsterdam market led to a growing emphasis on grain production and, hence, better dikes. During this period, new farms with large storage capacities, the socalled Gulfhaus type, were built along the coast from Holland to Denmark (Nitz 1989). 
Figure 3.1 The town of Bolsward (Friesland) originated as two dwelling mounds in a tidal landscape. Upper part: Actueel Hoogtebestand Nederland; lower part: Hisgis, with additions.
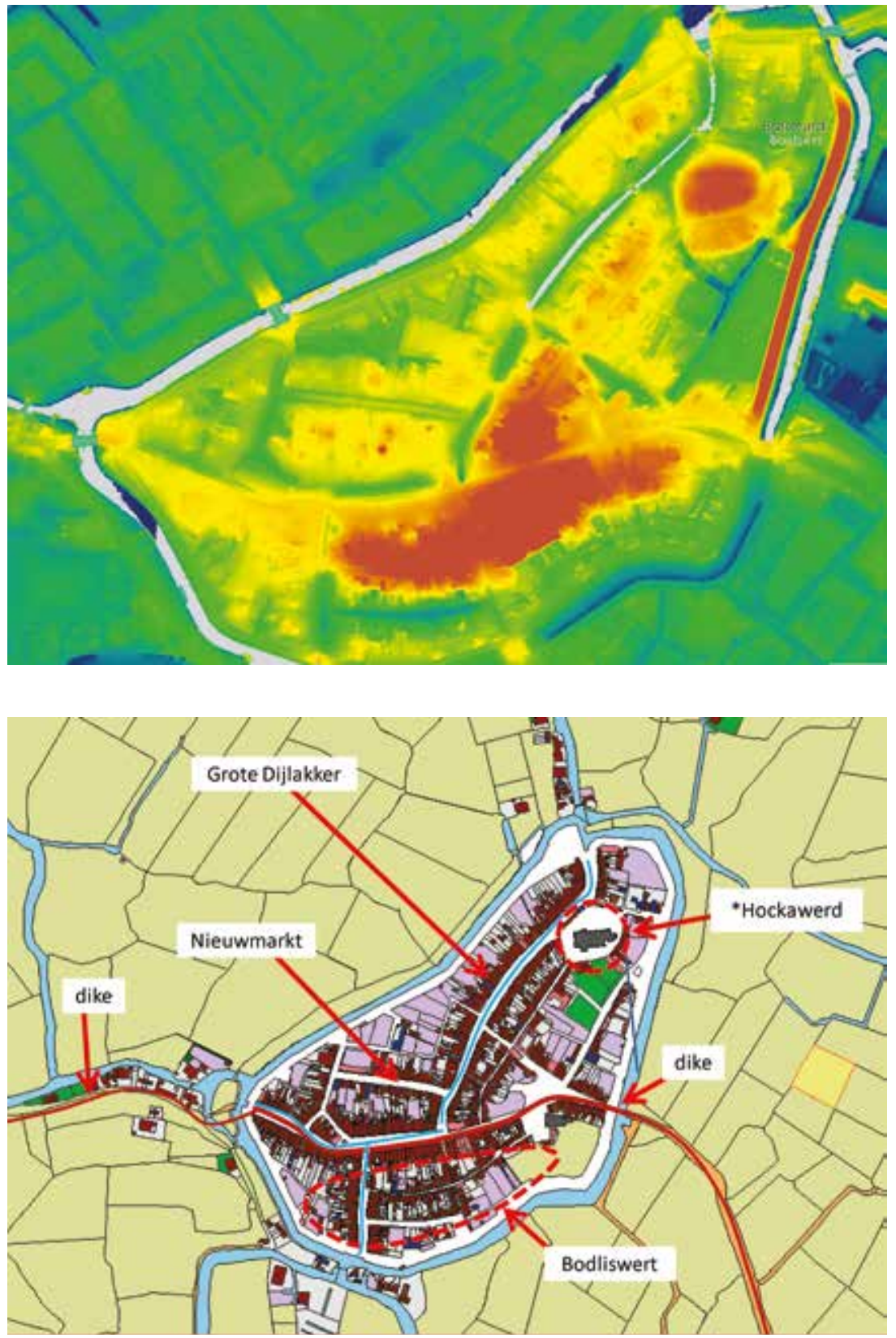

Cartography by Ton Markus, Faculty of Geosciences, Utrecht University 
Figure 3.2 The Slachtedijk/Zeedijk at Oosterbierum. A number of stones mark past stages in the heightening of the dike.

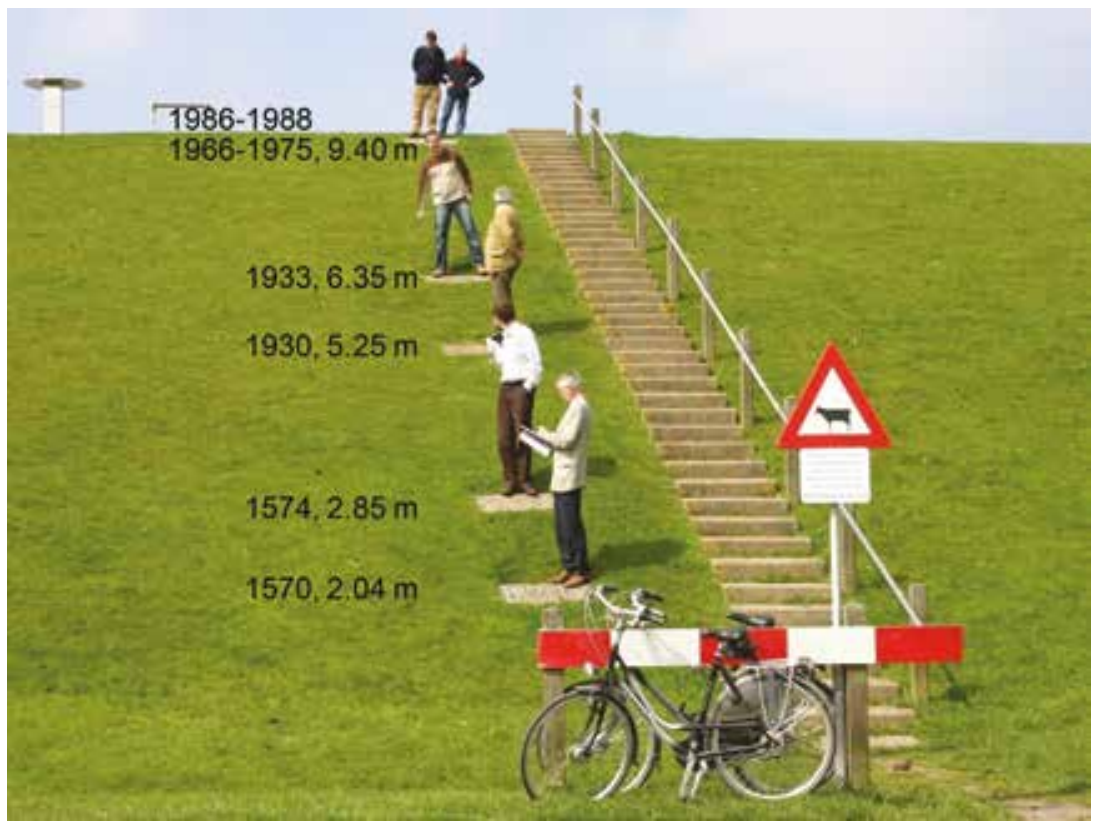

Data by Sytse Keizer

Outside the dikes, the situation remained dynamic. With every storm, parts of the fenlands eroded, and in the course of the Middle Ages most of the fen settlements were lost. Partly this loss was man-induced, as reclamations of fenlands led to oxidation of peat and hence to the subsidence of land. The earliest settlements in the western Wadden Sea, which we find in sources from the eighth and ninth centuries by place names ending with 'more', have all disappeared. In parts of the Wadden Sea, the loss of land continued in early modern or even modern times, although in most parts, the loss and accretion of land were more or less in balance during the post-medieval period. Many of the islands lost land on one side and grew on the other. But lost as well as new lands were part of human society. The lost lands became fishing grounds and some of the lost settlements had an afterlife in folk tales and other types of collective memory. The new lands were used as pasture and often, when silted up high enough, were surrounded by dikes and transformed into arable land.

The dikes have been raised over time, making them into ever sharper borders (figure 3.2; De Raad 1993; Hosper et al. 2001: 37). The Wadden Sea region is nowadays characterised by a sharp division between land and 
Figure 3.3 Ponds in the coastal marshes of North Friesland (near the village of Hallum).

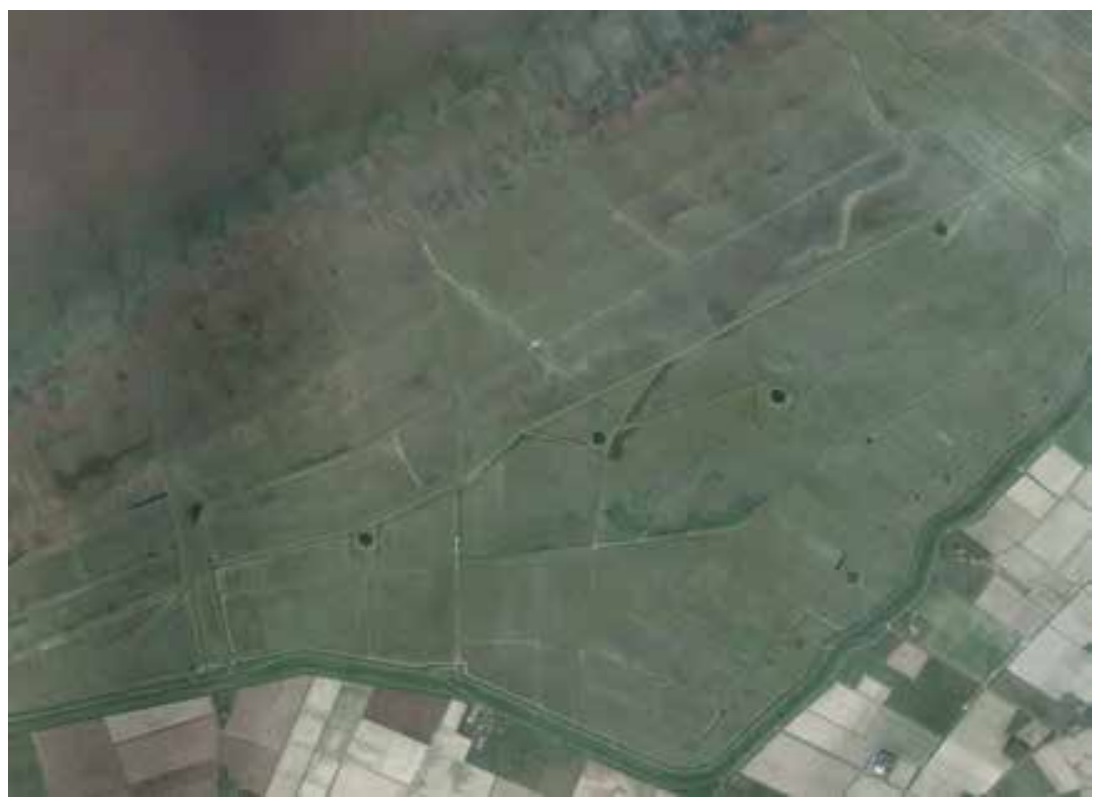

Source: Google Earth

sea. But still, the division is not absolute. The sea is visited and exploited from the land. Farmers still use the saltmarshes as pasture. In the marshes on the Frisian coast, a number of ponds, surrounded by small dikes, show the use of this floodplain as pasture (figure 3.3; Vroom 2013). In the past, this use of pasture was earlier or later followed by the building of a sea dike and reclamation with the aim of creating arable land. The last of such plans, in the marshes shown on figure 3.3, was abolished after much discussion in 1979 by the national government with the words: potatoes are good for Friesland, but the Wadden Sea is more beautiful (De Raad 1993: 122-124). The last large reclamation project was the Lauwersmeer, a former sea inlet that was cut off from the Wadden Sea in 1969 but was never used for its original purposes: villages were not built, agriculture took up only a small part, and the use of the land as military training ground stopped after the end of the Cold War. Now its main function is 'nature', but for that, the present situation is inferior to the earlier tidal lands. Now, plans are being made to reintroduce tidal movements in the area, softening the border between land and sea (Programma Rijke Waddenzee 2017). 
But there is more. In the marshes as well as on the islands, the combination of agriculture and shipping remained a characteristic feature throughout the early modern and modern periods. The Groningen geographer Gerrit Smit (1971) described the island of Terschelling as an agrarian-maritime economy. Islands in particular have a history of economic and demographic fluctuations. Agriculture was combined with shipping and fishing (Table 3.2). The activities on water and on land influenced each other, and this relation often reflected economic fluctuations in the wider world (Renes 2014). When both types of activities became problematic, temporary or permanent emigration took place. In periods in which shipping and fishing prospered, agriculture may have received less attention, as there was sufficient income to buy goods from elsewhere. On many islands in Europe, a substantial part of the male population was at sea for part of the year, leaving the women, together with children and elderly people, responsible for agriculture. This could mean that a substantial proportion of the women never left the island, whereas the men travelled the whole world - a gender-specific polarisations in experiences (Renes 2014). However, in periods in which maritime activities were less successful, the whole island population fell back on agriculture and islands became more self-supporting.

Table 3.2 A model for relations between sailing/fishing, agriculture and population size

\begin{tabular}{|c|c|c|}
\hline \multirow{2}{*}{$\begin{array}{l}\text { Sailing / } \\
\text { fishing }\end{array}$} & \multicolumn{2}{|l|}{ Agriculture } \\
\hline & Good & Bad \\
\hline Good & $\begin{array}{l}\text { Population growth, very intensive land use } \\
\text { (mainly women and elderly people) }\end{array}$ & Neglect of agriculture \\
\hline Bad & Population growth, very intensive land use & Emigration \\
\hline
\end{tabular}

The Dutch Wadden islands, for example, had important fishing fleets during the late Middle Ages but afterwards lost them as a result of competition from the mainland. The islanders continued fishing but on ships owned by mainlanders (Smit 1971: 2). During the seventeenth and eighteenth centuries, many men from the Wadden islands sailed on Amsterdam or Hamburg-owned whaling fleets (Brouwer 1936: 11; Kelm 2008: 132). The sailors not only came from the Dutch Wadden Sea islands but also from the German and Danish parts of the Wadden Sea. In 1720, a quarter of the total population of Nordmarsch was engaged in whaling (Riecken 1982: 30). In many churchyards, as in Amrum and Rømø, gravestones refer to the importance of whaling and shipping (figure 3.4). 
Figure 3.4 Gravestones of whalers at St Clemens churchyard on the German island of Amrum (a, b) and at Kirkeby on the Danish island of Rømø (c).
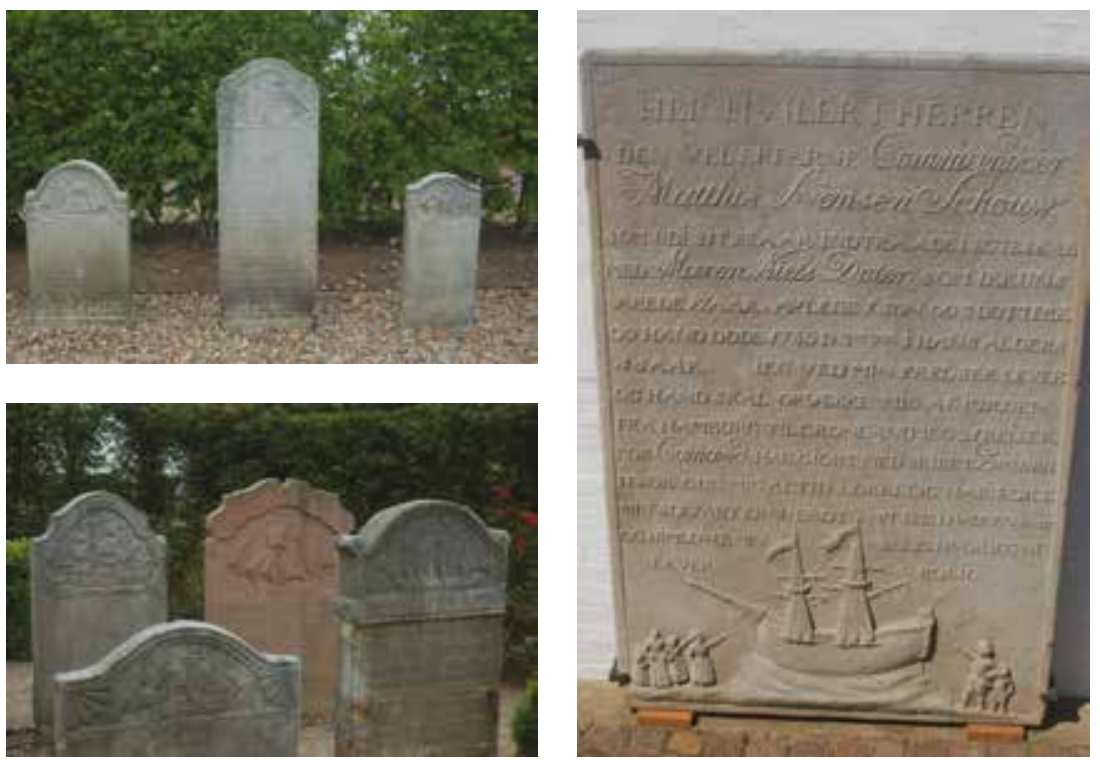

Photos by author

All these sectors were highly fluctuating. The role of agriculture on the Wadden islands was different for each island. Many of the larger islands had a strong agricultural basis. Examples include Texel, Terschelling and Ameland. But also agriculture experienced fluctuations. In periods of high population pressure, islands could show forms of agrarian involution (a term coined by Geertz 1968), leading to an extreme fragmentation of land ownership. Systems of partible inheritance - which emerged in situations where paucity had to be shared and that could result in an extreme fragmentation of land ownership - were typical for many islands.

The Dutch Wadden island of Ameland may be seen as an example of these processes (Abrahamse et al. 2005). During the seventeenth century, people from Ameland sailed along the North Sea coasts to France and to the Baltic. Between $165^{\circ}$ and 1750, some 80 ships with a captain from Ameland passed the sound between Denmark and Sweden each year (Faber 1972: 603). In addition, sailors from Ameland and other Wadden Islands formed an important part of the crews of seventeenth and eighteenth-century whaling ships, and when the Wadden Island fleets disappeared from the middle of the eighteenth century, the islanders kept working in whaling ships. When whaling declined during the eighteenth century, they moved 
Figure 3.5 The oldest house on the island of Ameland (Johan Bakkerstraat 7, Hollum) is a so-called 'commandeurs' house. In the early nineteenth century a shed was added, converting the house into a farm. The front gives the date 1516, but it is suggested that the figures are mixed up and different authors give 1561, 1615 or 1651 as the probable building date.

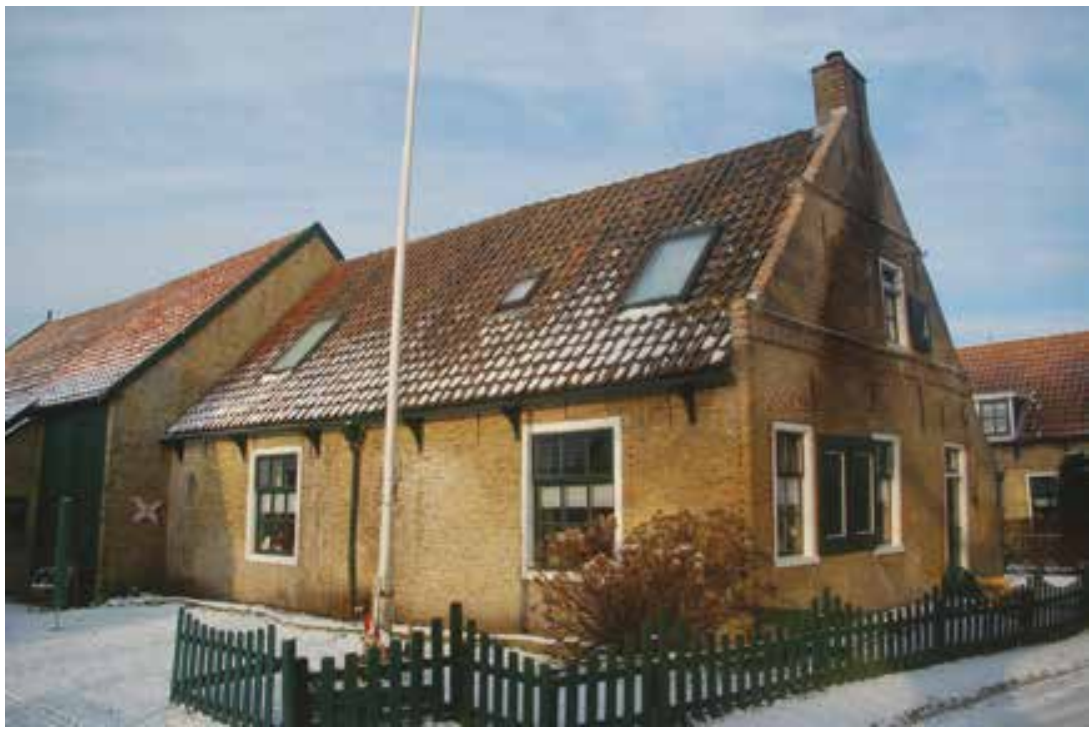

Photo by author

into long-distance shipping. During the nineteenth century, however, many sailors on Ameland, especially the most prosperous, left for the mainland, and agriculture regained a more dominant position.

A number of what are known as 'commanders' houses' (commandeur was the local term for the captain of a whaling ship) were converted into farms at this time (figure 3.5; Brouwer 1936:11). However, the extreme fragmentation of land, which was not a problem while agriculture was a side activity, gradually came to be seen as problematic. In 1885,140 out of a total of 219 farmers used less than 5 hectare and only 15 used more than 10 hectare (although using rights on the commons should be added to this figure; Brouwer 1936: $35,54-58)$. Originally, the hay meadows were periodically redistributed so that every farmer received a number of dispersed fields. When the periodic redistribution was abolished, the most recent allocations were made permanent, and thereafter partible inheritance caused further fragmentation (Brouwer 1936: 23). In the village of Ballum, for example,when voluntary land consolidation was carried out (the first one in the Netherlands), as many as 
Figure 3.6 Population and occupations in Terschelling 1900-2000.
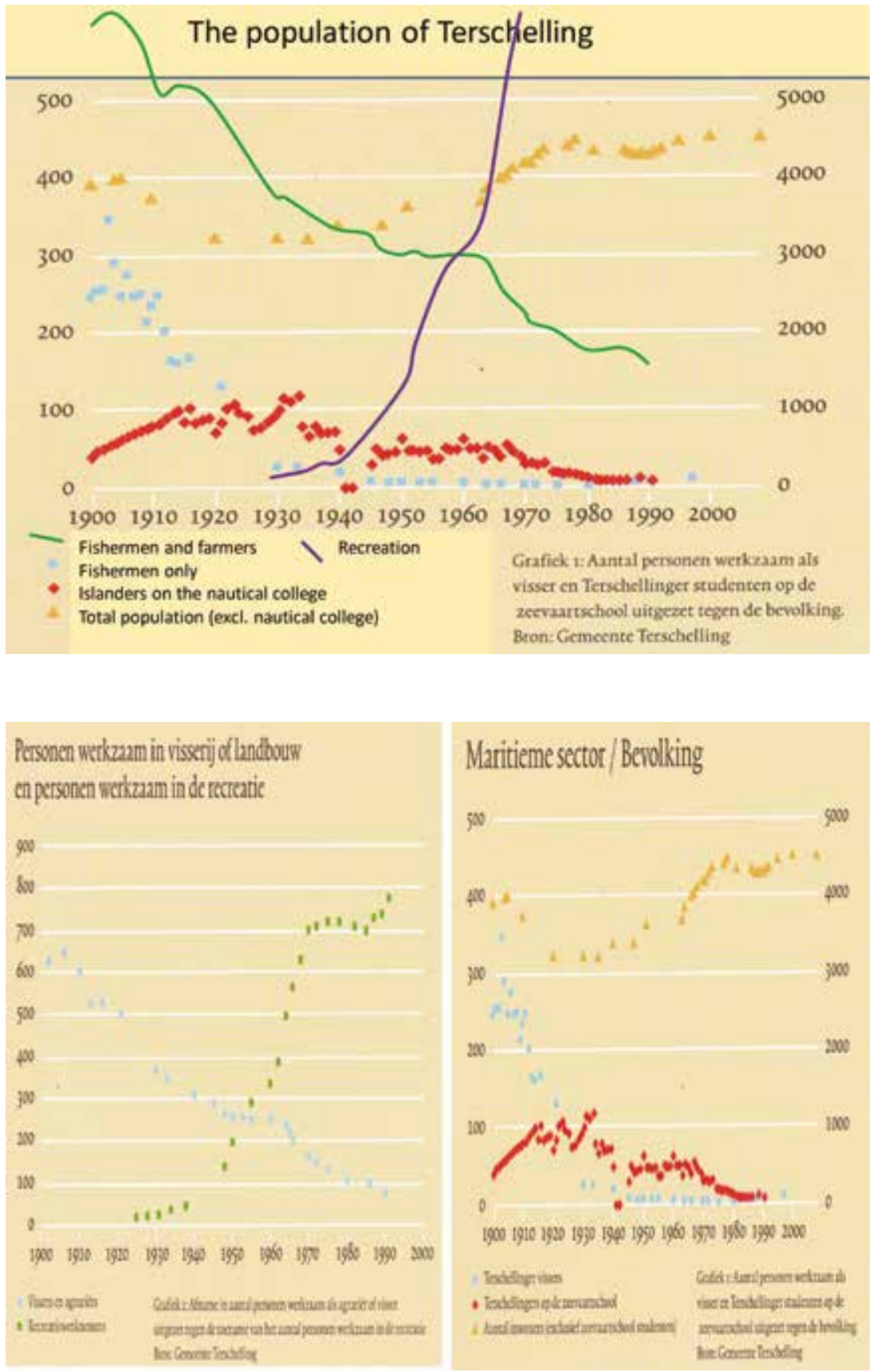

After Hoekstra et al., 2009. Drawing: by Ton Markus, Faculty of Geosciences, Utrecht University 
2,000 fields with an average size of 0.085 hectares were owned by only 119 people (Groeneveld 1985: 34-41; Brouwer 1936: 89-91). In the neighbouring village of Hollum, the situation was even worse, with 272 owners owning 4,897 pieces of land, with arable land and hay meadows being particularly fragmented. Consolidation was delayed until 1925, when the new national Land Consolidation Law made it possible to overrule the four remaining opponents (Groeneveld 1985: 39; Brouwer 1936: 91-94).

During the twentieth century, the position of farming on the islands became ever more difficult. One reason was the limited possibility to enlarge the scale of agriculture, but changes in transport also played a role. In the past, islands could be competitive, as transport by boat was cheaper and easier than over the bad inland roads. Nowadays, land transport is faster and cheaper. Island agriculture can survive by specialisations, for example in organic agriculture, or by additional activities, for example in recreation. Many farmers derive part of their income from operating camp sites, renting out rooms and selling farm products. Between 1978 and 1995, the Wadden island of Ameland transported its milk to the mainland by a pipeline, the first of its kind; it is now used for a fibre optic connection, which is another way to lessen the isolation of island inhabitants (Ameland Info 2018).

Some data on Terschelling show that large fluctuations in the economy and in employment continued to occur in the twentieth century (figure 3.6). Fishing and shipping survived, but the number of people working in these sectors dwindled. The same was true for farming. Particularly during the second half of the twentieth century, recreation was the main growth sector. On many European islands, the success of the leisure industry has been the main factor behind the growth or decline of population numbers (Renes 2014). As this graph shows, Terschelling has been successful in building up its tourism industry and the population is still growing.

Tourist facilities are concentrated on the islands, but tourism again is an activity that connects land with water. Just like well-trained ecologists, many tourists concentrate on places where different biotopes meet, such as the beaches where the land meets the sea. Many other tourists do sailing trips on the Wadden Sea, and they see visits to the coast or the islands as an additional attraction. Also 'wad hiking' (Dutch: wadlopen) — walking between the mainland and one of the islands at low tide — is a rather popular activity. And let us not forget: people who visit islands are not looking for land overseas, they are looking for an island.

So, throughout history, the marshes and islands have been characterised by a mixed economy. Although the relative importance of each of the economic pillars fluctuated, the system as a whole remained intact until the 
present day. The fluctuations, particularly in agriculture, had yet another effect. Periods of high pressure resulted in 'pressure cooker landscapes' with very high densities of landscape features. Periods of agrarian and demographic crises often meant a certain degree of neglect of the landscape, in which many features were preserved. The combination has made many islands into important heritage ensembles (Renes 2014).

\section{Nature, landscape and the future of the Wadden Sea region}

This brings me to the final part of this chapter: the present and future management of the Wadden Sea. The region combines high heritage values (Bazelmans et al. 2012) with high ecological values. There is a tendency to look to the land for heritage and to the sea (and the dunes) for nature (Egberts 2017). However, the historical overview above has demonstrated that the history of the Wadden Sea region started with an extremely soft, flexible and permeable land-water interface. Even during the last 1,00o years, when ever higher and stronger dikes became a borderline between the land and the sea, the interaction between the two continued and in fact was - and still is - not only a barrier but also a connection between the land and the sea, for example where farmers use the marshes on the seaside and where people climb the dike to view the sea.

It is governments and politicians in particular as well as ecologists that uphold the Cartesian division of the Wadden Sea area into land and water and into the domains of man and nature. In this context, it may be useful to look again at the Wadden Sea's World Heritage status. The World Heritage List started in 1972, and from the start a strict division between natural and cultural sites was used. Two different NGOs were put in charge of the reviewing process: the natural sites were reviewed by the International Union for the Conservation of Nature (IUCN) and the cultural nominations by the International Commission on Monuments and Sites (ICOMOS). The weakness of this system became clear when landscapes were nominated. In 1987 , the United Kingdom proposed the Lake District as a mixed (nature and culture) site. ICOMOS agreed, but for IUCN the region was insufficiently 'natural'. In 1989, the Lake District was therefore proposed as a cultural site, based on a Neolithic site in Langdale. In response, ICOMOS concluded that the finds would justify inscription for that specific valley, but not for the region as a whole. Then, during one of its periodic bouts of isolationism, the UK withdrew from UNESCO, only to return again in 1997. In the meantime, the Lake District case had given rise to intensive discussions within UNESCO, 
leading to the 1992 reformulation of the category of 'cultural landscapes' (Droste et al. 1995; Rössler 2006). In addition to the existing definition of designed landscapes, two new categories were added: 'continuous' (or 'living') landscapes and 'associative landscapes'. The first meant that typical man-made landscapes, which surpass the distinction between nature and culture and which by definition included continuous change, could now be added to the list. Even more innovative was the addition of 'associative landscapes', which were usually regarded as natural or semi-natural but were part of human society as a result of their significance for the regional communities. In all, UNESCO turned the failure of the Lake District proposal into a new vision of the nature-culture interface in landscapes. The new category of cultural landscapes - as reflections of the life and history of people and for their aesthetic qualities - became a successful category. The United Kingdom prepared a new nomination for the Lake District as a cultural landscape, at the same time adding the new argument that the Lake District was associated with the early interest in mountain landscapes by the poet William Wordsworth and the founders of the National Trust. The Lake District was inscribed on the World Heritage List in 2017.

In my opinion, redefining the Wadden Sea region (including coasts and islands) as a cultural landscape is a necessary step towards the future management of the region. This will certainly be opposed by the main advocates of the framing of the region as 'nature' - i.e. many (but not all) ecologists and governments/politicians. A case in point is the Dutch Ministry of Economic Affairs, Agriculture and Innovation, which took over nature conservation from the abolished Ministry of Agriculture, Nature and Food Quality in 2010. The former Ministry had a long-standing reputation for being the political arm of the so-called Green Front, the cooperation of farmers' organizations, politicians and researchers that made the Netherlands into a successful agricultural producer. Within this lobby, the Ministry of Agriculture was notorious for defending the short-term interests of the large agrarian producers. In 1983, the Ministry annexed its main opponent, the nature conservation department of the Ministry of Culture, Recreation and Welfare. Within the new Ministry, an elegant and workable situation was created in which farmers got a free hand in go percent of the rural areas and the remaining 10 percent was designated as 'nature', which was gradually bought from the farmers and turned into new wilderness.

The main victim of this historical compromise was landscape, which could not be traded off in hectares but would influence both the agricultural lands and the new wilderness. As a result, the ministry overlooked landscape policies almost completely, although it never admitted to doing 
so. It is a policy that has caused unsolved problems, for example in the Dutch contributions to the World Heritage List. Quite a few of the Dutch sites on the list are typical cultural landscapes but were not allowed to be listed as such. For example, the former island of Schokland is listed as an archaeological site, the Beemster drained lake is listed as a work of art, and the ring of inundation zones with additional fortresses around Amsterdam is mainly defined as a collection of fortresses with surrounding lands.

In this political context, it is understandable that the Dutch Ministry of Agriculture was a key player in the lobby to list the Wadden Sea as a natural site only. But it was precisely the nomination of a natural site, together with the fundamentalist definitions used by the IUCN, which led to a model in which nature - which is mainly the Wadden Sea sensu stricto - is separated from the cultural landscapes of the coasts and the islands. Although many economic activities still take place in the Wadden Sea, such as gas and salt exploration, there seems to be very little interest in the basic unity of the region.

Still, there are developments in the opposite direction. Dynamic coastal management is beginning to replace the earlier macho-management of ever higher and straighter dunes by a softer border (Dynamisch Kustbeheer 2017). Another recent example are the plans of the village of Holwerd in Friesland to dig a canal to the Wadden Sea and thereby restore its connection to the sea that was lost with the medieval building of the sea dikes (Holwerd aan Zee 2017). The plan's main aim is economic stimulus, but it is also very symbolic for a village that is trying to overcome its centuries-long isolation from the sea.

The future of the Wadden Sea is dependent on human society. Predictions by the Delta Commission (Samen werken 2008) are that the Wadden Sea will survive the first half of the twenty-first century but may be inundated as a result of the sea level rise in the second half of this century. So in the longer term, the survival of the characteristic Wadden landscape is at stake. In my opinion, no policy will be successful without the involvement of the population of the region. The integrating and dynamic concept of cultural landscape could be a major contribution to the discussions.

\section{References}

Aa, B.J.M. van der, P.D. Groote and P.P.P. Huigen (2004). World heritage as NIMBY?

The case of the Dutch part of the Wadden Sea. Current Issues in Tourism, 9, 291-302. Abrahamse, J., M. Bemelman and M. Hillinga (eds.) (2005). Wadden, verhalend landschap. Baarn/Wilhelmshaven: Tirion/Common Wadden Sea Secretariat. 
Ameland Info (2018). Kabelbuis. Retrieved January 24, 2018 from: https://www. ameland.info/tag/damverbinding/

Bazelmans, J. D. Meier, A. Nieuwhof, T. Spek and P. Vos (2012). Understanding the cultural historical value of the Wadden Sea Region. The co-evolution of environment and society in the Wadden Sea area in the Holocene up until early modern times (11,700 BC-1800 AD). An outline. Ocean and Coastal Management, 68, 114-26.

Brouwer, D.A. (1936). Ameland; Een sociaal-geografische studie van een Waddeneiland. Amsterdam: Paris.

Donraadt, W.C. (1972). Zij waren er bij; Eilanders op de walvisvaart. Schiermonnikoog.

Droste, B. von, H. Plachter \& M. Rössler (eds.) (1995). Cultural landscapes of universal value. Jena: Fischer.

Dynamisch Kustbeheer (2017). Dynamisch kustbeheer op de Waddeneilanden. Retrieved August 29, 2017 from: http://www.dynamischkustbeheer.nl/content/ content.asp?menu=1062000o_oooooo

Egberts, L. (2017). Voorbij de harde grens. Een cultuurhistorisch toekomstperspectief voor het Nederlandse Waddengebied. In: Visies op de Wadden: Zes essays ten behoeve van de Beleidsverkenning Toekomstige Rol en Ambitie van het Rijk voor het Waddengebied, pp. 30-47. Leeuwarden: Waddenacademie.

Faber, J.A. (1972). Drie eeuwen Friesland. Economische en sociale ontwikkelingen van 1500 tot 1800 (A.A.G. Bijdragen 17). Wageningen: Veenman.

Geertz, C. (1968). Agricultural involution: The process of ecological change in Indonesia. Berkeley: University of California Press.

Groeneveld, J. (1985). Veranderend Nederland: Een halve eeuw ontwikkelingen op het platteland. Maastricht: Natuur \& Techniek.

Hoekstra, H., Zijlstra, E., Zwart, F., Smit-Zwanenburg, E., and Kok, J.P. (2009). Een eeuw badgasten. Een beeld van noo jaar toerisme op Terschelling. Terschelling: Isola Arte.

Holwerd aan Zee (2017). Retrieved August 29, 2017 from: https://www.holwerdaanzee.nl/nld/.

Hosper, U., Karstkarel, P. and Woude, S. van der (2001). De Slachte:De oude dijk, de geschiedenis, de landschappen, de dorpen, de marathon. Leeuwarden: Friese Pers.

Janssen, J., Luiten, E., Renes, H. \& Stegmeijer, E. (2017). Heritage as sector, factor and vector: Conceptualizing the shifting relationship between heritage management and spatial planning. European Planning Studies, 25 (9), 1654-1672.

Kelm, B. (2008). Rømø - von der Nordsee geprägt. Geschichte einer Insel und ihre Bewohner. Bräist: Nordfriisk Instituut.

Knol, E. (2005). Rijke en aantrekkelijke kustlanden. Noord-Nederland in de vroege middeleeuwen. In: Knol, E., Bardet, A.C. and Prummel, W. (eds.), Professor Van Giffen en het geheim van de wierden (pp. 183-93). Veendam/Groningen: Heveskes/ Groninger Museum. 
Knottnerus, O.S. (2004). Yeomen and farmers in the Wadden Sea coastal marshes, c. 1500-c. 1900. In: Bavel, B.J.P. van, and Hoppenbrouwers, P. (eds.), Landholding and land transfer in the North Sea area (late Middle Ages-19th century), pp. 149-86. Turnhout: Brepols.

Krauss, W. (2005). The natural and cultural landscape heritage of Northern Friesland. International Journal of Heritage Studies, 11, 39-52.

Kullberg, J. (1992). Bolsward, gebouwd op terpen. Utrecht: Matrijs.

Lotze, H.K., Reise, K., Worm, B., Beusekom, J.van, Busch, M., Ehlers, A., Heinrich, D., Hoffmann, R.C., Holm, P., Jensen, C., Knottnerus, O.S., Langhanki, N., Prummel, W., Vollmer, M., and Wolff, W.J. (2005). Human transformations of the Wadden Sea ecosystem through time: A synthesis. Helgoland Marine Research, 59, 84-95.

Nitz, H.J. (1989). Transformation of old and formation of new structures in the rural landscape of northern central Europe during the 16th to 18th centuries under the impact of the early modern commercial economy. Tijdschrift van de Belgische Vereniging voor Aardrijkskundige Studies 58, 267290.

Marrewijk, D. van (2001). Wad 'n plek, de beleving van de Waddenzeeregio. In: Marrewijk, D. van and Haartsen, A. (eds.). Waddenland. Het landschap en cultureel erfgoed in de Waddenzeeregio (pp. 165-173). Leeuwarden: LanceWad Nederland/Noordboek.

Olwig, K.R. (2002). Landscape nature and the body politic: From Britain's Renaissance to America's New World. Madison: University of Wisconsin Press.

Olwig, K.R. (2006). Introduction: The nature of cultural heritage, and the culture of natural heritage - Northern perspectives on a contested patrimony. In: Lowenthal, D. \& Olwig, K. (eds.), The nature of cultural heritage, and the culture of natural heritage (pp. 1-5). London: Routledge.

Programma Rijke Waddenzee (2017). Project: Verkenning duurzame kansen Lauwersmeer-Waddenzee. Retrieved August 25, 2017 from: https://rijkewaddenzee.nl/project/verkenning-duurzame-kansen-lauwersmeer-waddenzee/.

Raad, H. de (1993). De dijk op hoogte. Harlingen: Waterschap Fryslan.

Renes, H. (2014). Islandscapes; isolation and pressure. Landscapes 15 (1), 44-58.

Riecken, G. (1982). Die Halligen im Wandel. Husum: Husum Druck- und Verlagsges.

Rössler, M. (2006). World Heritage Cultural Landscapes: a UNESCO Flagship Programme 1992-2006. Landscape Research, 31 (4), 333-353.

Samen werken met water. Een land dat leeft, bouwt aan zijn toekomst. Bevindingen van de Deltacommissie 2008 (2008). Deltacommissie, n.pl.

Smit, G. (1971). De agrarisch-maritieme struktuur van Terschelling omstreeks het midden van de negentiende eeuw. Groningen: Sasland/Leeuwarden: Miedema.

Vroom, M. (2013). Gras upt werp. Landschapsbiografie en draagvlakanalyse voor het huidige beheer van het kwelderlandschap van Noord-Friesland Buitendijks. Unpublished MA-thesis Groningen. 
Warren, C.R. (2009). Wilderness. In Kitchin, R. \& Thrift, N. (eds.). International Encyclopedia of Human Geography, Volume 1 (pp. 254-259). Oxford: Elsevier. Westerdahl, C. (1992). The maritime cultural landscape. The International Journal of Nautical Archaeology, 21, 5-14.

\section{About the author}

Prof. Hans Renes is a historical geographer at Utrecht University (Faculty of Geosciences) and Professor of Heritage Studies at Vrije Universiteit Amsterdam (Faculty of Humanities). He has published on many different aspects of the landscape history of the Netherlands and Europe as well as on the relationship between landscape heritage and planning. 
